\title{
İnstructional Leadership Behaviors of School Administrators on the İmplementation of Secondary School Curricula
}

\author{
Hızır Zorlu ${ }^{1} \&$ Ayla Arseven ${ }^{2}$ \\ ${ }^{1}$ Ministry of Education, Sivas, Turkey \\ ${ }^{2}$ Department of Primary Education, Faculty of Education, Cumhuriyet University, Sivas, Turkey \\ Correspondence: Ayla Arseven, Department of Primary Education, Faculty of Education, Cumhuriyet University, \\ Sivas, Turkey. Tel: 90-346-219-1010/ 46 57. E-mail: aylaarseven2004@yahoo.com
}

Received: July 17, 2015

Accepted: January 20, 2016

Online Published: January 25, 2016

doi:10.5430/ijhe.v5n1p276

URL: http://dx.doi.org/10.5430/ijhe.v5n1p276

This article is written by a section of Huzır Zorlu's master's thesis.

\begin{abstract}
The aim of this study is to determine instructional leadership behaviors of secondary school administrators based on the perceptions of administrators and teachers. The study was carried out with 309 teachers and 68 school administrators working in 25 secondary schools in Turkey. The study was carried out with the descriptive survey research. The "Instructional Leadership Scale" was used in the study. "Simple random sampling" method was used in the sample selection. In the analysis of tha data; frequency, arithmetic mean, t-test, one way variance analysis and Dunnett's T3 test statistics have been used.

According to the results of the study, in all dimensions teachers' perceptions of instructional leadership behaviors are lower compared to administrators' perceptions. There is a significant difference between the administrators' perceptions of their own level of instructional leadership and the teachers' perceptions of administrators' instructional leadership. While the teachers' perceptions of school administrators' instructional leadership do not vary in terms of gender, it exhibits variance in terms of length of service.
\end{abstract}

Keywords: Secondary school curricula, Teachers, School administrator, Instructional leadership behavior

\section{Introduction}

Throughout the history, human beings have met their need for manpower through education. Education, whether planned, formal or more traditional and informal, occurs in every environment. Especially, for educational institutions, which have a more planned or programmed structure, to reach their aims, administrators are one of the most important factors and they are expected to be qualified people. With its broadest definition, education is a social process which affects interpretations of internal and external events, setting goals, designing activities, individual motivation and skills, power relations and common characteristics (Hoy and Miskel, 2010). While Drucker (1996) states that definition of leadership can vary according to ones who make the definition, the theme common to all definition is the word "effect" and he also states that leaders can exists as long as they influence the behaviors and emotions of their followers (Özmen, 2003). Leadership is not a passive status. An individual is not given the attribution of being a leader just because s/he has the mixture of some certain characteristics. A leader can gain the status of leadership through interaction with the group. In achieving this status, it is important to exhibit that s/he has the power to help the group to achieve its aims through interaction (Aydın, 2010). The leader, as the member of the group, has a positive influence on the other members of the group. In other words, a leader is the member of the group who has more positive effect on the other members of the group (Başaran, 1998). Leader identifies the vision, aims, priorities, and standards of the organization and takes necessary precautions not to spoil them and to compromise them (Drucker, 1996).

Leadership behaviors play a great role for educational organizations to reach success. Since the mid-1980s, studies on school leadership have focused on the activities of school administrators, who are one of the members of school community. The best conclusion drawn from these studies is that strong administrative leadership, that is, strong instructional leadership, is a part of structural and program change (Camburn, Rowan and Taylor 2003). When various studies have been examined, it is seen that there are many definitions with regard to instructional leadership. 
De Bevoise (1984) defined instructional leadership as behaviors administrators exhibit themselves or behaviors they cause others to exhibit to increase students' success. According to Daresh amd Chingjen (1985), instructional leadership is school administrators' behaviors that directly or indirectly affect teaching and learning situations. According to Şişman (2004), instructional leadership behaviors can be defined as behaviors that administrators exhibit themselves and that the behaviors they make others exhibit by influencing them. Instructional leadership was developed in relation with school administration and focuses on instruction (Çelik, 2003). Instructional leadership can help the school to develop its aims effectively. In schools, by emphasizing instructional leadership and by attaching importance to the roles instructional leaders play, quality of education can be increased (Yörük and Akdağ, 2010). Therefore, it is the process of making decisions with regard to carrying the schools from their existing status to their ideal status. In this process, the instructional leadership roles that school administrators take over can help schools achieve success. Therefore, the first step to be taken is to make the concept of instructional leadership concept clearer. Later on, leadership qualities and behaviors required to fulfill this leadership role are to be identified (Özdemir and Sezgin, 2000).

Researchers examined instructional leadership at various sub-dimensions, In this study, the dimensioning by Şişman (1997) was taken into consideration.

Determining and Sharing the Aims of School: Instructional activities can be planned and implemented in line with aims only when these aims are grasped. Therefore, school must have a clear aim and this aim is to increase students' success. School principal is expected to lead in the determination of school's aims (Şişman, 2004).

Management of Educational Program and Instructional Process: The production plan for a school is the same as the one for an organization producing services. Therefore, managing a school means managing an Educational Program (Başaran, 1994). Management of Educational Program involves distribution of courses according to teachers' branches, annual and daily lesson plans, arranging of commemoration and celebration events (Erdoğan, 2008).

Assessment of Education Process and Students: Assessment is a process which involves actions for evaluation and improvement. It is seen as an important function of the continuing procession of an organization (Aydin, 2010). A successful instructional leader is aware of the fact that students' improvement can be assessed and should be assessed, and should know various assessment techniques.

Supporting Teachers and their Professional Development: Although it is teachers' own responsibility to develop themselves, administrations also play a significant role. The opportunity to accept and realize the desire for continuous development can be only possible with the support and participation of school administration because incompetency of subordinates cause a management problem that should concern administrators (Açikalın, 1997). School administrator should contribute to professional development of teachers and it is one of the most important duties of leaders to give necessary contribution in this process.

Creation of Organized Learning-Teaching Environment and Atmosphere: The school atmosphere means the working conditions and the effects of these conditions on people. The school atmosphere has a versatile effect on individuals' motivation, integration with school, spirits and performance (Şişman, 2004).

\subsection{Educational Programs and Instructional Leadership}

The raison d'etre and the only aim for educational organizations is to educate students according to the aims of education and students are trained according to the education program. Therefore, school management means the management of Educational Program and instruction (Başaran, 1991). A school manager as an instructional leader is to actively take part in the school program, selection, provision and distribution of instructional materials. To achieve learning outcomes at expected levels at schools, the inputs (education program, printed materials instructional technologies, physical and financial resources, education staff and time) are to be integrated effectively. School administrators as instructional leaders are to provide teachers with necessary resources so that they can carry out education activities effectively. School administrators should set an example for school staff in making use of new and different instructional resources. S/he should give constructive feedback to school staff in terms of effective use of instructional resources (Özdemir, 2000).

\subsection{The Purpose of the Study}

The current study aims to determine the perceptions of school administrators' and teachers' working in secondary schools with regard to instructional leadership behaviors of school administrators in the application of secondary school education programs, and to examine whether teachers' perceptions vary according to gender and length of service. The study is significant in that there are problems encountered in the application process of educational programs and the number studies on this issue in our country is low (Arslan 2009; Derbedek 2008; Öztaş 2010; Sağır 
2011). Answers for the following questions have been sought:

1. What are the perceptions of teachers and administrators with regard to "Determining and Sharing the Aims of the School", which is one of the sub-dimensions of instructional leadership?

2. What are the perceptions of teachers and administrators with regard to "Management of Educational Program and Instructional Process", which is one of the sub-dimensions of instructional leadership behaviors?

3. What are the perceptions of teachers and administrators with regard to "assessment of Instructional Process and Students", which is one of the sub-dimensions of instructional leadership behaviors?

4. What are the perceptions of teachers and administrators with regard to "Supporting Teachers and their Professional Development", which is one of the sub-dimensions of instructional leadership behaviors?

5. What are the perceptions of teachers and administrators with regard to "Creation of Organized Teaching-Learning Environment and Atmosphere", which is one of the sub-dimensions of instructional leadership behaviors?

6. Is there a significant difference between teachers' and school administrators' working in secondary schools with regard to school administrators' instructional leadership behaviors?

7. Do the perceptions of teachers working in secondary schools with regards to instructional leadership behaviors of school administrators vary in terms of such variables as gender and length of service?

\section{Methodology}

To determine the perceptions of school administrators' and teachers' working in secondary schools with regard to instructional leadership behaviors of school administrators in the application of secondary school curricula, and to examine whether teachers' perceptions vary according to gender and length of service in this study descriptive survey research was used. A survey design provides a quantitative or numeric description of trends, attitudes, or opinions of a population by studying a sample of that population (Creswell, 2013).

\subsection{Population and Sample}

The population of the study is composed of 1316 teachers and 128 school administrators (48 school principals and 80 vice-principals) working in 48 state schools in Sivas city center in Turkey (excluding the villages and towns) affiliated with the Ministry of Education in 2013-2014. Based on the population of the study and using the "simple random sampling "method, 309 teachers and 68 school administrators working in 25 schools in the central district of Sivas province were taken as the sample. The amount of deviation for the population estimated $(\mathrm{d}=.05)$ and confidence level $(1$-alpha) $=0.95$ was obtained.

To provide for the appropriate sample $\mathrm{p}=0.5$ was taken and $\mathrm{q}=(1-\mathrm{p}), \mathrm{q}=0.5$ is found, $\mathrm{p} . \mathrm{q}=0.25$. $\mathrm{t}$ values corresponding to the confidence level is 1,96 .

$\mathrm{n}_{0}=\left(\mathrm{t}^{2} \mathrm{x} \mathrm{pq}\right) / \mathrm{d}^{2}$ when we put values in the formula;

$\left.\mathrm{n}_{0}=\left(1,96^{2}\right) \quad \mathrm{x} 0,25\right) / 0,05^{2}=0,9604 / 0,0025=384,16$

$\mathrm{n}=\mathrm{n}_{0} /\left[1+\left(\mathrm{n}_{0}-1\right) / \mathrm{N}\right]$ when we put values $\mathrm{n}_{0}$ and $\mathrm{N}$ in the formula;

$\mathrm{n}=384,16 /[1+(384,16-1) / 1316]=384,16 / 1,2911=297,54$;

$\mathrm{n}=298$ can be taken.

Findings with regard to genders of participants and participants' length of service are given in Table 1.

Table 1. Distribution of participants in terms of gender and their length of service

\begin{tabular}{|c|c|c|c|c|c|c|}
\hline \multicolumn{2}{|c|}{ Teacher } & f & $\%$ & Administrator & f & $\%$ \\
\hline \multirow{6}{*}{ 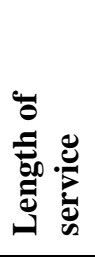 } & $1-5$ years & 71 & 23,0 & $1-5$ years & - & 0 \\
\hline & 6-10 years & 93 & 30,1 & $6-10$ years & - & 0 \\
\hline & $11-15$ years & 60 & 19,4 & $11-15$ years & 10 & 14,7 \\
\hline & $16-20$ years & 45 & 14,6 & $16-20$ years & 24 & 35,3 \\
\hline & 21 years and over & 40 & 12,9 & 21 years and over & 34 & 50 \\
\hline & Total & 309 & 100,0 & Total & 68 & 100 \\
\hline \multirow{3}{*}{ ذّ } & Female & 166 & 53,7 & Female & - & 0 \\
\hline & Male & 143 & 46,3 & Male & 68 & 100 \\
\hline & Total & 309 & 100,0 & Total & 68 & 100 \\
\hline
\end{tabular}


When Table 1 is examined, it is seen that out of 309 teachers 166 were female and 143 were male. While female participants make up $53.7 \%$ of total participants, male account for $46.3 \%$. All of the 68 school administrators are all male. Following from here, it is seen that females do not take part in school administration.

It is seen from the table that $71(23 \%)$ out of 309 teachers who participated in the study have 1 to 5 years of length of service, $93(30,1 \%)$ of them had 6 to 10 years of length of service, $60(19,4 \%)$ of them had 11 to 15 years of length of service, $45(14,6 \%)$ of them had between 16 to 20 years of length of service, $40(12,9 \%)$ had service length of 21 years and over. According to the results, the number of teachers with service length of 6 to 10 years is the highest. The reason for this is the fact that the study was carried out in the central district and teachers first work various locations before they are appointed to the central district.

Out of 68 administrators participating the study, $10(14.7 \%)$ had 11 to 15 years of length of service, $24(35 \%)$ had 16 to 20 years of length of service and $34(50 \%)$ had 21 years and over length of service. In this case, most of the administrators have longer length of service as administrators are to work as a teacher for some period to be an administrator and the administrators in the central district have longer length of service.

\subsection{Data Collection}

To determine instructional leadership behaviors studies carried out in Turkey and abroad have been examined. As a result of review, it was decided that "Instructional Leadership Behaviors of School Administrators Scale" developed by Şişman (2004) be used in the study. Instructional leadership behaviors in the scale consist of five dimensions: "determining and sharing the purpose of the school", "management of curricula and instruction process", "assessment of education process and students", "supporting teachers and their development" and "creating an organized learning-teaching environment and atmosphere". The answers to the questions are rated as: 1 (never), 2 (very rare), 3 (occasionally), 4 (most of the time) and 5 (always). The range of the five rating scale is defined as 0.80 . According to the results of validity and reliability test by Öztaş (2010), the alpha values for the scale were found to be $.96, .95, .95, .94$ and .95 . According to the results of the factor analysis, facctor loads ranges between 0,514 and 0,881 . In the factor analysis of instructional education, a sound factorial structure has been revealed. Therefore, as factor loads are high, it is seen that questions share a common variance with other questions. Means of data collection was administrated by the researcher herself or by the teachers and school administrators. The return rate was increased by asking the school administration's help.

\subsection{Data Analysis}

Data collected to determine instructional leadership behaviors of school administrators was analyzed using the SPSS software package. When analyzing research data, the questions of the study have been taken into consideration. Frequency, arithmetic mean and standard deviation values were calculated to determine teachers' and school administrators' perceptions of instructional leadership. To determine whether there was a significant difference between instructional leadership perceptions of school administrators and teachers and whether teachers' instructional leadership perceptions vary in terms of gender, t-test was administrated. Besides, one way variance analysis was applied to determine whether teachers' instructional leadership perceptions vary in terms of their length of service. According to the Levene statistics $(\mathrm{p}=.00<.05)$ it was observed that the variance is not homogeneous. So, to find out on whether which groups related to the instructional leadership behaviors of school administrators, Dunnett's T3 test was performed.

\section{Results}

\subsection{Teachers' and Administrators' Perceptions with the regard to the Determining and Sharing the School's Aims}

Findings with regard to teachers' and administrators' perceptions of the sub-dimension of "determining and sharing the school's aims" are given in Table 2. 
Table 2. Teacher and administrators perceptions of the determining and sharing the school's aims

\begin{tabular}{|c|c|c|c|c|}
\hline Instructional leadership behaviors & Groups & $\mathbf{N}$ & $\overline{\mathbf{X}}$ & sd \\
\hline \multirow{2}{*}{$\begin{array}{l}\text { 1. Explaining the overall aims of the school to the } \\
\text { teachers and students }\end{array}$} & \multirow{2}{*}{$\begin{array}{l}\text { Teacher } \\
\text { Adminis. }\end{array}$} & 309 & 3.55 & 96 \\
\hline & & 68 & 4,20 & ,93 \\
\hline \multirow{2}{*}{$\begin{array}{l}\text { 2. Encouraging everyone in the school to share the aims } \\
\text { of the school }\end{array}$} & \multirow{2}{*}{$\begin{array}{l}\text { Teacher } \\
\text { Adminis. }\end{array}$} & 309 & 3,48 & .89 \\
\hline & & 68 & 4,01 & ,90 \\
\hline \multirow[t]{2}{*}{ 3. Reviewing the aims of the school and updating them } & Teacher & 309 & 3,41 & ,95 \\
\hline & Adminis. & 68 & 4,47 &, 58 \\
\hline \multirow{2}{*}{$\begin{array}{l}\text { 4. Making use of students' success when developing the } \\
\text { aims of the school }\end{array}$} & \multirow{2}{*}{$\begin{array}{l}\text { Teacher } \\
\text { Adminis. }\end{array}$} & 309 & 3,57 & ,91 \\
\hline & & 68 & 4,47 &, 58 \\
\hline \multirow{2}{*}{$\begin{array}{l}\text { 5. Enhancing the compatibility between school's aims } \\
\text { and courses }\end{array}$} & \multirow{2}{*}{$\begin{array}{l}\text { Teacher } \\
\text { Adminis. }\end{array}$} & 309 & 3,50 &, 86 \\
\hline & & 68 & 4,02 & ,91 \\
\hline \multirow{2}{*}{$\begin{array}{l}\text { 6. Opening the schools' aims for discussion in board } \\
\text { meetings }\end{array}$} & \multirow{2}{*}{$\begin{array}{l}\text { Teacher } \\
\text { Adminis. }\end{array}$} & 309 & 3,65 & ,96 \\
\hline & & 68 & 3,94 & 1,02 \\
\hline \multirow[t]{2}{*}{ 7. Encouraging teachers to work for the same aims } & Teacher & 309 & 3,60 & ,91 \\
\hline & Adminis. & 68 & 4,10 & 1,03 \\
\hline \multirow{2}{*}{$\begin{array}{l}\text { 8. Setting objectives to increase students' current level } \\
\text { of success }\end{array}$} & \multirow{2}{*}{$\begin{array}{l}\text { Teacher } \\
\text { Adminis. }\end{array}$} & 309 & 3.69 & 96 \\
\hline & & 68 & 4,14 &, 81 \\
\hline \multirow{2}{*}{$\begin{array}{l}\text { 9. Pioneering in putting the aims of the school into } \\
\text { practice }\end{array}$} & \multirow{2}{*}{$\begin{array}{l}\text { Teacher } \\
\text { Adminis. }\end{array}$} & 309 & 3,49 & ,92 \\
\hline & & 68 & 4,23 &, 79 \\
\hline \multirow{2}{*}{$\begin{array}{l}\text { 10. Encouraging everyone to have high expectations } \\
\text { with regard to students' success }\end{array}$} & \multirow{2}{*}{$\begin{array}{l}\text { Teacher } \\
\text { Adminis. }\end{array}$} & 309 & 3,49 &, 89 \\
\hline & & 68 & 3,91 & 1,04 \\
\hline \multirow[t]{2}{*}{ Determining schools aims and sharing them (Mean) } & Teacher & 309 & 3,54 &, 65 \\
\hline & Adminis. & 68 & 4,11 & ,39 \\
\hline
\end{tabular}

When Table 2 is examined, it is seen that teachers were of the opinion that school administrators most of the time "set objectives to increase students' current level of success" ( $\bar{X}=3,69)$, "opened the schools' aims for discussion in board meetings" ( $\bar{X}=3,65)$, "encouraged teachers to work for the same aim" ( $\bar{X}=3,60)$, all of which are among the sub-dimensions of "determining and sharing school's aims". The responds teachers provided to the questions related to administrators' behaviors in the sub-dimension of "determination of school's aims and sharing them" was "Most of the Time" with a mean value of $\bar{X}=3,54$.

The school administrators stated that they "Most of the Time" made use of student's current level of success when setting objectives $(\bar{X}=4,47)$, " pioneered in putting the aims of the school into practice $(\bar{X}=4,23)$, "explained the overall aims to teachers and students " $(\overline{\mathrm{X}}=4,20)$, which are the instructional leadership behaviors under the sub-dimension of "Determining and Sharing School's Aims". School Administrators "encouraged everyone to have high expectations for student success" $(\overline{\mathrm{X}}=3,91)$, "opened the schools aims for discussion in board meetings" $(\overline{\mathrm{X}}=$ $3,94)$, "encouraged everyone to share the aims of the school " $\bar{X}=4,01)$. It is seen that the weighted means of the responds school administrators gave to the questions under the sub-dimensions "Determined the Aims of School and Shared Them" is "Most of the Time" with a weighted mean of $\bar{X}=4,11$. 


\subsection{Teachers' and Administrators Perceptions of Management of Educational Program and Instructional Process}

Table 3. Teachers' and Administrators Perceptions of Management of Educational Program and Instructional Process

\begin{tabular}{|c|c|c|c|c|}
\hline Instructional leadership Behaviors & Groups & $\mathbf{N}$ & $\overline{\mathbf{X}}$ & sd \\
\hline \multirow{2}{*}{$\begin{array}{l}\text { 11. Preparing annual activity report about school's } \\
\text { educational activities }\end{array}$} & \multirow{2}{*}{$\begin{array}{l}\text { Teacher } \\
\text { Administrator }\end{array}$} & 309 & 3,89 & ,96 \\
\hline & & 68 & 4,16 &, 85 \\
\hline \multirow{2}{*}{$\begin{array}{l}\text { 12. Attaching importance to taking students' needs and } \\
\text { expectations into consideration in the school's program }\end{array}$} & \multirow{2}{*}{$\begin{array}{l}\text { Teacher } \\
\text { Administrator }\end{array}$} & 309 & 3,62 &, 81 \\
\hline & & 68 & 4,42 &, 73 \\
\hline \multirow{2}{*}{$\begin{array}{l}\text { 13. Achieving coordination between the } 1^{\text {st }} \text { and } 2^{\text {nd }} \text { levels } \\
\text { of educational programs in the school }\end{array}$} & \multirow{2}{*}{$\begin{array}{l}\text { Teacher } \\
\text { Administrator }\end{array}$} & 309 & 3,40 &, 86 \\
\hline & & 68 & 4,40 &, 75 \\
\hline \multirow{2}{*}{$\begin{array}{l}\text { 14. Actively participating in evaluation and selection of } \\
\text { materials (book, journal etc.) about the program }\end{array}$} & \multirow{2}{*}{$\begin{array}{l}\text { Teacher } \\
\text { Administrator }\end{array}$} & 309 & 3,06 & 1,14 \\
\hline & & 68 & 3,54 & 1,02 \\
\hline \multirow{2}{*}{$\begin{array}{l}\text { 15. Visiting classes to ensure the effective use of in-class } \\
\text { instruction time }\end{array}$} & \multirow{2}{*}{$\begin{array}{l}\text { Teacher } \\
\text { Administrator }\end{array}$} & 309 & 2,88 & 1,07 \\
\hline & & 68 & 3,70 &, 62 \\
\hline \multirow{2}{*}{$\begin{array}{l}\text { 16. Encouraging extracurricular social, cultural and } \\
\text { educational activities }\end{array}$} & \multirow{2}{*}{$\begin{array}{l}\text { Teacher } \\
\text { Administrator }\end{array}$} & 309 & 3,38 & 1,01 \\
\hline & & 68 & 4,41 &, 67 \\
\hline \multirow{2}{*}{$\begin{array}{l}\text { 17. Ensuring that students' come to class on time and } \\
\text { prevent their interference with the class }\end{array}$} & \multirow{2}{*}{$\begin{array}{l}\text { Teacher } \\
\text { Administrator }\end{array}$} & 309 & 3,32 & ,97 \\
\hline & & 68 & 4,25 &, 59 \\
\hline \multirow[t]{2}{*}{ 18. Ensuring that classes start and finish on time } & Teacher & 309 & 3,82 & ,91 \\
\hline & Administrator & 68 & 4,51 &, 50 \\
\hline \multirow{2}{*}{$\begin{array}{l}\text { 19. Spending most of the time in the school by } \\
\text { observing and participating in educational environments }\end{array}$} & Teacher & 309 & 3,32 & 1,01 \\
\hline & Administrator & 68 & 4,02 &, 51 \\
\hline \multirow{2}{*}{$\begin{array}{l}\text { 20. Preventing the interruption of classes via announces } \\
\text { or calling students from classrooms }\end{array}$} & \multirow{2}{*}{$\begin{array}{l}\text { Teacher } \\
\text { Administrator }\end{array}$} & 309 & 3,18 & 1,17 \\
\hline & & 68 & 4,01 &, 57 \\
\hline \multirow[t]{2}{*}{$\begin{array}{l}\text { Management of Educational Program and } \\
\text { instructional process }\end{array}$} & \multirow{2}{*}{$\begin{array}{l}\text { Teacher } \\
\text { Administrator }\end{array}$} & 309 & 3,39 & ,65 \\
\hline & & 68 & 4,14 &, 25 \\
\hline
\end{tabular}

When Table 3 is examined, it is seen that according to the teachers' perceptions, the school administrators' "most of the time" "prepared annual activity report about school's educational activities" $(\overline{\mathrm{X}}=3,89)$, "spend most their time at school by observing and participating in educational environments" $(\overline{\mathrm{X}}=3,82)$ " and "attached importance to taking students' needs into consideration in the school program $(\bar{X}=3,62)$ ", which are among the behaviors in the sub-dimension of "Management of Educational Program and Instructional Process". According to the teachers, the school administrators "occasionally" "prevented the interruption of classes with announces or calling students from classrooms" $(\bar{X}=3,18)$, "actively took part in the evaluation and selection of materials (books, journals etc.) for the program" $(\bar{X}=3,06)$, "visited classes to ensure the effective use of in-class time" $(\bar{X}=2,88)$. The average of the teachers' responds with regard to the school administrators' exhibition of behaviors categorized under the sub-dimension of "Management of Educational Program and Instructional Process" was "Occasionally" with weighted mean of $\quad \overline{\mathrm{X}}=3,39$. 
The school administrators stated that with regard to the leadership behaviors in the sub-dimension of "Management of Educational Program and Instructional Process", they "ensured that classes start and finish on time" ( $\overline{\mathrm{X}}=4,51)$, "attached importance to students' needs and expectations in the school program " ( $\bar{X}=4,42)$, and "encouraged extracurricular social, cultural and educational activities" ( $\overline{\mathrm{X}}=4,41$ ), "Always". The school administrators think that they "Most of the Time" "actively participated in evaluation and selection of materials about (book, journal etc.) the program" ( $\overline{\mathrm{X}}=3,54)$, "visited classes to increase the effectiveness of in-class instructional time" $(\overline{\mathrm{X}}=3,70)$, " prevented the interruption of classes with announcements or calling students from classes" $(\overline{\mathrm{X}}=4,02)$. The average of the school administrators responds to the questions with regard to their behaviors categorized in the sub-dimension of "Managing Educational Program and Instructional Process" was "Most of the Time" with a weighted mean of $\overline{\mathrm{X}}=4,14$.

\subsection{Teachers and Administrators Perceptions of Assessment of Instructional Process and Students}

Table 4. Teachers' and Administrators' perceptions of Assessment of Instructional Process and Students

\begin{tabular}{lllll}
\hline Instructional leadership behaviors & Groups & $\mathbf{n}$ & $\overline{\mathbf{X}}$ & sd \\
\hline 21. Speaking with teachers to discuss students level of & Teacher & 309 & 3,44 &, 98 \\
success & Administrator & 68 & 4,30 &, 60 \\
22. Consulting with teachers to determine strengths & Teacher & 309 & 3,25 &, 98 \\
and weaknesses of the educational programs & Administrator & 68 & 4,04 &, 77 \\
23. Revising school program according to exam results & Teacher & 309 & 3,24 & 1,07 \\
and making necessary amendments & Administrator & 68 & 3,86 &, 68 \\
24. Determining students needing special instruction & Teacher & 309 & 3,33 & 1,07 \\
and interest & Administrator & 68 & 3,85 &, 62 \\
25.Informing students' about school's and students' & Teacher & 309 & 3,38 &, 93 \\
level of success & Administrator & 68 & 4,26 &, 63 \\
26. Informing teachers with regard to school's level of & Teacher & 309 & 3,62 &, 94 \\
success written or orally & Administrator & 68 & 4,77 &, 45 \\
27. Rewarding students successful at class level or at & Teacher & 309 & 3,53 & 1,07 \\
school level & Administrator & 68 & 4,48 &, 68 \\
28. Explaining teachers important issues with regard to & Teacher & 309 & 3,16 & 1,06 \\
instruction after in-class observation & Administrator & 68 & 3,94 &, 78 \\
29. Revising student works when assessing in-class & Teacher & 309 & 3,14 & 1,04 \\
teaching & Administrator & 68 & 3,76 &, 93 \\
30. Being in direct contact with students to talk about & Teacher & 309 & 3,35 & 1,02 \\
problems in school & Administrator & 68 & 3,95 &, 76 \\
Assessment of Instruction process and students & Teacher & $\mathbf{3 0 9}$ & $\mathbf{3 , 3 4}$ & $\mathbf{, 7 7}$ \\
(Mean) & Administrator & $\mathbf{6 8}$ & $\mathbf{3 , 9 5}$ & $\mathbf{, 7 6}$ \\
\hline
\end{tabular}

When Table 4 is examined, it is seen that the teachers who took part in the study stated that among the behaviors under the sub-dimension of "Assessment Instructional Process and Students" school administrators exhibited the following behaviors "Most of the Time": "informing teachers about the school's level of success written or orally" $(\overline{\mathrm{X}}$ $=3,62)$ "rewarding successful students at school and class level" $(\bar{X}=3,53)$, "interviewing teachers to discuss students' level of success" $(\overline{\mathrm{X}}=3,44)$. The teachers stated that the school administrators "Occasionally" "revised student works when assessing in-class teaching" $(\overline{\mathrm{X}}=3,14)$, "explained teachers important issues with regard to instruction after in-class observation" ( $\overline{\mathrm{X}}=3,16)$, "revised school programs and made neccessary changes according to exam results" ( $\overline{\mathrm{X}}=3,24)$, which are in the sub-dimension of "Assessment of Instructional Process and Students". The average of the teachers' responds with regard to school administrators' behaviors in the sub-dimension of "Assessment of Instructional Process and Students" is "Occasional" with weighted means of $\overline{\mathrm{X}}=3,34$.

The school administrators stated that among the leadership behaviors in the sub-dimension of "Assessment of 
Instructional Process and Students", they "Always" exhibited the behaviors of "informing teachers about school's level of success written or orally" ( $\overline{\mathrm{X}}=4,77)$, " rewarding students successful at class level or at school level " $(\overline{\mathrm{X}}$ $=4,48)$, and the behavior of "consulting with teachers to discuss students' level of success" ( $\bar{X}=4,30)$. The school administrators think that they "Most of the Time" exhibited the behaviors of "revising students' works when assessing in-class instruction" ( $\overline{\mathrm{X}}=3,76)$, "determining students with special teaching and interest according to exam results" ( $\overline{\mathrm{X}}=3,85)$, "revising school program and making necessary changes according to exam results" ( $\overline{\mathrm{X}}=4,86)$. The school administrators responded to the questions with regard to the frequency they exhibited the behaviors categorized in the sub-dimension of "Assessment of Instructional Process and Students" as "Most of the Time" with a weighted mean of $\overline{\mathrm{X}}=3,95$.

3.4 Teachers' and Administrators' Perceptions of Sub-dimension of Supporting Teachers and their Professional Development

Table 5. Teachers' and Administrators' perceptions of the Sub-dimension of Supporting Teachers and their Professional Development

\begin{tabular}{|c|c|c|c|c|}
\hline Instructional Leadership Behaviors & Groups & $\mathbf{n}$ & $\overline{\mathbf{X}}$ & sd \\
\hline \multirow{2}{*}{$\begin{array}{l}\text { 31. Encouraging teachers to exhibit high level of } \\
\text { performance }\end{array}$} & Teacher & 309 & 3,39 & 1,01 \\
\hline & Adminis. & 68 & 4,04 &, 85 \\
\hline \multirow{2}{*}{$\begin{array}{l}\text { 32. Complimenting teachers for their outstanding efforts } \\
\text { and success }\end{array}$} & Teacher & 309 & 3,19 & 1,08 \\
\hline & Adminis. & 68 & 4,26 &, 78 \\
\hline \multirow{2}{*}{$\begin{array}{l}\text { 33. Complimenting teachers in writing for their } \\
\text { outstanding efforts }\end{array}$} & Teacher & 309 & 2,55 & 1,10 \\
\hline & Adminis. & 68 & 2,77 & ,94 \\
\hline \multirow{2}{*}{$\begin{array}{l}\text { 34. Arranging in-service training events for teachers } \\
\text { professional development }\end{array}$} & Teacher & 309 & 2,77 & 1,18 \\
\hline & Adminis. & 68 & 3,02 & ,96 \\
\hline \multirow{2}{*}{$\begin{array}{l}\text { 35. Informing teachers about opportunities to develop } \\
\text { themselves professionally }\end{array}$} & Teacher & 309 & 3,11 & 1,03 \\
\hline & Adminis. & 68 & 4,02 &, 73 \\
\hline \multirow{2}{*}{$\begin{array}{l}\text { 36. Supporting teachers who put in efforts to develop } \\
\text { professionally (in-service training, graduate education etc.) }\end{array}$} & Teacher & 309 & 3,21 & 1,08 \\
\hline & Adminis. & 68 & 4,22 & 68 \\
\hline \multirow{2}{*}{$\begin{array}{l}\text { 37. Copying the papers on education in newspaper and } \\
\text { journals and distributing them to teachers }\end{array}$} & Teacher & 309 & 2,41 & 1,12 \\
\hline & Adminis. & 68 & 3,04 & 1,12 \\
\hline \multirow[t]{2}{*}{ 38. Calling speakers to give conferences to teachers } & Teacher & 309 & 2,32 & 1,12 \\
\hline & Adminis. & 68 & 2,76 & ,93 \\
\hline \multirow{2}{*}{$\begin{array}{l}\text { 39. Arranging meetings to share new knowledge and skills } \\
\text { acquired in-service education }\end{array}$} & Teacher & 309 & 2,66 & ,99 \\
\hline & Adminis. & 68 & 3,01 & ,90 \\
\hline \multirow{2}{*}{$\begin{array}{l}\text { 40. Supporting teachers to use new knowledge and skills } \\
\text { acquired during in-service education in class }\end{array}$} & Teacher & 309 & 2,87 & 1,03 \\
\hline & Adminis. & 68 & 3,63 & 89 \\
\hline \multirow{2}{*}{$\begin{array}{l}\text { Supporting } \quad \text { Teachers } \quad \text { and } \\
\text { Development }(\text { Overall Average) }\end{array}$} & Teacher & 309 & 2,85 & ,78 \\
\hline & Adminis. & 68 & 3,47 & ,44 \\
\hline
\end{tabular}

When Table 5 is examined, it is seen that the teachers agreed that the school administrators "Occasionally" exhibited the behaviors of "complimenting teachers for their outstanding efforts and success" ( $\overline{\mathrm{X}}=3,19)$, "supporting teachers who put in efforts to develop professionally (in-service training, graduate education etc.)" $(\overline{\mathrm{X}}=3,21)$, "encouraging teachers to exhibit high level of performance $(\overline{\mathrm{X}}=3,39)$, which are among the behaviors in the sub-dimension of "Supporting and Developing Teachers". They also stated that the administrators exhibited the behaviors of "calling speakers to give conferences to teachers" $(\overline{\mathrm{X}}=2,32)$, "copying the papers on education published in newspapers and journals and distributing them" $(\overline{\mathrm{X}}=2,41)$, "appreciating teachers in writing for their special efforts" $(\overline{\mathrm{X}}=2,55)$ "Very Rarely". The mean of the responds teachers provided with regard to the frequency of the behaviors school administrators exhibited under sub-dimension of "Supporting Teachers and their Professional Development" is "Occasionally" ( $\overline{\mathrm{X}}=2,85)$. 
The school administrators think that they exhibited the behaviors of "complimenting teachers' efforts and accomplishments" $(\bar{X}=4,26)$, "supporting teachers who put in efforts to develop professionally ( in-service training, graduate education etc.)" ( $\overline{\mathrm{X}}=4,22)$ "Always", and that they exhibited the behavior of "informing teachers about opportunities for professional development" ( $\overline{\mathrm{X}}=4,02)$ "Most of the Time". The school administrators think that they exhibited the behaviors of "calling speakers to give conferences to teachers" ( $\overline{\mathrm{X}}=2,76)$, and "arranging meetings to share new information and skills obtained during in-service training" ( $\overline{\mathrm{X}}=3,01)$, "arranging in-service training for teachers' professional development" $(\overline{\mathrm{X}}=3,02)$ "Occsaionally". The responds given by the school administrators to the questions about the frequency they exhibited the behaviors in the sub dimension of "Supporting Teachers and their Professional Development" is "Most of the Time" ( $\overline{\mathrm{X}}=3,47)$.

3.5 Teachers and Administrators Perceptions of the Sub-Dimension of Creating an Organized Learning-Teaching Environment and Atmosphere

Table 6. Teachers and Administrators Perceptions of the Sub-Dimension of Creating an Organized Learning-Teaching Environment and Atmosphere

\begin{tabular}{|c|c|c|c|c|}
\hline Instructional Leadership Behaviors & Groups & $\mathbf{N}$ & $\overline{\mathbf{X}}$ & SS \\
\hline \multirow{2}{*}{$\begin{array}{l}\text { 41. Encouraging "team spirit" among administrators, } \\
\text { teachers, students and other staff }\end{array}$} & \multirow{2}{*}{$\begin{array}{l}\text { Teacher } \\
\text { Administrator }\end{array}$} & 309 & 3,16 & 1,02 \\
\hline & & 68 & 3,98 & ,99 \\
\hline \multirow[t]{2}{*}{ 42. Supporting teachers to do their jobs better } & Teacher & 309 & 3,33 & ,91 \\
\hline & Administrator & 68 & 4,70 & ,45 \\
\hline \multirow{2}{*}{$\begin{array}{l}\text { 43. Ensuring organization and discipline necessary for } \\
\text { effective teaching and learning }\end{array}$} & \multirow{2}{*}{$\begin{array}{l}\text { Teacher } \\
\text { Administrator }\end{array}$} & 309 & 3,26 & 1,02 \\
\hline & & 68 & 4,41 & ,62 \\
\hline \multirow[t]{2}{*}{ 44. Instilling the belief that all students can learn at school } & Teacher & 309 & 3,32 & ,94 \\
\hline & Administrator & 68 & 4,23 & ,62 \\
\hline \multirow{2}{*}{$\begin{array}{l}\text { 45. Creating a school environment in which students and } \\
\text { teachers can work with pleasure }\end{array}$} & \multirow{2}{*}{$\begin{array}{l}\text { Teacher } \\
\text { Administrator }\end{array}$} & 309 & 3,10 & 1,04 \\
\hline & & 68 & 4,05 &, 70 \\
\hline \multirow{2}{*}{$\begin{array}{l}\text { 46. Encouraging social activities that will ensure } \\
\text { coalescence among teachers and students }\end{array}$} & \multirow{2}{*}{$\begin{array}{l}\text { Teacher } \\
\text { Administrator }\end{array}$} & 309 & 3,06 & 1,06 \\
\hline & & 68 & 4,02 &, 75 \\
\hline \multirow{2}{*}{$\begin{array}{l}\text { 47. Supporting teachers with new ideas and different ideas } \\
\text { about education }\end{array}$} & \multirow{2}{*}{$\begin{array}{l}\text { Teacher } \\
\text { Administrator }\end{array}$} & 309 & 3,23 & ,99 \\
\hline & & 68 & 4,60 &, 55 \\
\hline \multirow{2}{*}{$\begin{array}{l}\text { 48. Preventing harms to school because of conflicts } \\
\text { between individuals and groups }\end{array}$} & \multirow{2}{*}{$\begin{array}{l}\text { Teacher } \\
\text { Administrator }\end{array}$} & 309 & 3,43 &, 94 \\
\hline & & 68 & 4,63 &, 51 \\
\hline \multirow{2}{*}{$\begin{array}{l}\text { 49. Prioritizing educational activities when allocating time } \\
\text { and sources }\end{array}$} & \multirow{2}{*}{$\begin{array}{l}\text { Teacher } \\
\text { Administrator }\end{array}$} & 309 & 3,37 & ,93 \\
\hline & & 68 & 4,08 & ,68 \\
\hline \multirow{2}{*}{$\begin{array}{l}\text { 50. Ensuring family and environment support for student } \\
\text { success }\end{array}$} & \multirow{2}{*}{$\begin{array}{l}\text { Teacher } \\
\text { Administrator }\end{array}$} & 309 & 3,43 & ,94 \\
\hline & & 68 & 4,30 & ,67 \\
\hline \multirow{2}{*}{$\begin{array}{l}\text { Creating teaching-learning environment and } \\
\text { atmosphere } \\
\text { (Overall mean) }\end{array}$} & \multirow{2}{*}{$\begin{array}{l}\text { Teacher } \\
\text { Administrator }\end{array}$} & 309 & 3,27 & ,76 \\
\hline & & 68 & 4,30 & ,27 \\
\hline
\end{tabular}


When Table 6 is examined, it is seen that the teachers who participated in the study think that the school administrators exhibited the behaviors of "preventing harm to school due to conflicts between individuals and groups" $(\bar{X}=3,43)$, "ensuring family and environment support for student success" $(\bar{X}=3,43)$ under the sub-dimension of "Creating an Organized Learning-Teaching Environment and Atmosphere". They stated that they exhibited the behaviors of "encouraging social activities that will ensure coalescence among teachers and students" $(\bar{X}=3,06)$, "creating a school environment in which students and teachers can work with pleasure" $(\overline{\mathrm{X}}=3,10)$, " encouraging "team spirit" among administrators, teachers, students and other staff $(\overline{\mathrm{X}}=3,16)$ "Occasionally ". The teachers responds with regard to the frequency school administrators exhibited behaviors in the sub dimension of "Creating an Organization Learning-Teaching Environment and Atmosphere" is "Occasionally" with a weighted mean of $\overline{\mathrm{X}}=3,27$.

The school administrators think that they "Always" exhibited the behaviors of "supporting teachers to do their jobs better" ( $\overline{\mathrm{X}}=4,70)$, "preventing harms to school due to conflicts between individuals and groups" $(\overline{\mathrm{X}}=4,63)$, "Supporting teachers with new and different ideas" which are in the sub-dimension of "Creating an Organized Learning-Teaching Environment and Atmosphere" ( $\overline{\mathrm{X}}=4,60)$. The school administrators think that they exhibited the behaviors of "encouraging raising team spirit among administrators, teachers, students and other staff" $(\overline{\mathrm{X}}=3,98)$ "Encouraging social activities that will ensure coalescence among teachers and students" $(\bar{X}=4,02)$, "preparing physical environments in school where students and teachers can work with pleasure" ( $\bar{X}=4,05)$ "Most of the Time". The responds school administrators provided to the questions about the frequency they exhibited the behaviors in the sub-dimension of "Creating organized learning-teaching environment" is "Always" with a weighted mean of $\overline{\mathrm{X}}=$ 4,30 .

\subsection{The Relation between Administrators and Teacher Perceptions of Instructional Leadership Behaviors}

Table 7. The Relation between Administrators and Teacher Perceptions of Instructional Leadership Behaviors

\begin{tabular}{|c|c|c|c|c|c|c|c|}
\hline $\begin{array}{l}\text { Sub-Dimensions of } \\
\text { the scale }\end{array}$ & Title & $\mathbf{N}$ & $\overline{\mathbf{X}}$ & $\mathbf{F}$ & $\mathbf{t}$ & Df & $\mathbf{p}$ \\
\hline \multirow{2}{*}{$\begin{array}{lr}\text { Determining } & \text { and } \\
\text { Sharing the school's } \\
\text { aims }\end{array}$} & Teacher & 309 & 3,54 & \multirow[t]{2}{*}{15,85} & \multirow[t]{2}{*}{$-9,34$} & \multirow[t]{2}{*}{157,68} & \multirow[t]{2}{*}{,00 } \\
\hline & Administrator & 68 & 4,11 & & & & \\
\hline \multirow{2}{*}{$\begin{array}{lr}\text { Management } & \text { of } \\
\text { Educational program } \\
\text { and instruction process }\end{array}$} & Teacher & 309 & 3,39 & \multirow[t]{2}{*}{39,76} & \multirow[t]{2}{*}{$-15,61$} & \multirow[t]{2}{*}{279,96} & \multirow[t]{2}{*}{, 00} \\
\hline & Administrator & 68 & 4,14 & & & & \\
\hline \multirow{2}{*}{$\begin{array}{l}\text { Assessment of } \\
\text { Education process and } \\
\text { students }\end{array}$} & \multirow{2}{*}{$\begin{array}{l}\text { Teacher } \\
\text { Administrator }\end{array}$} & 309 & 3,34 & \multirow[t]{2}{*}{32,26} & \multirow[t]{2}{*}{$-12,41$} & \multirow[t]{2}{*}{223,41} & \multirow[t]{2}{*}{, 00} \\
\hline & & 68 & 4,12 & & & & \\
\hline \multirow{2}{*}{$\begin{array}{l}\text { Supporting teachers } \\
\text { and their development }\end{array}$} & Teacher & 309 & 2,85 & \multirow[t]{2}{*}{28,43} & \multirow[t]{2}{*}{$-8,85$} & \multirow[t]{2}{*}{170,75} & \multirow[t]{2}{*}{, 00} \\
\hline & Administrator & 68 & 3,47 & & & & \\
\hline \multirow{2}{*}{$\begin{array}{lr}\text { Creating an organized } \\
\text { learning- } & \text { teaching } \\
\text { environment } & \text { and } \\
\text { atmosphere } & \end{array}$} & Teacher & 309 & 3,27 & \multirow[t]{2}{*}{48,31} & \multirow[t]{2}{*}{$-18,82$} & \multirow[t]{2}{*}{301,98} & \multirow[t]{2}{*}{, 00 } \\
\hline & Administrator & 68 & 4,30 & & & & \\
\hline
\end{tabular}

When Table 7 is examined, it is seen that as a result of t-test conducted to find out if there was a significant difference between the perceptions of branch teachers and school administrators who work in secondary schools with regard to instructional leadership behaviors of school administrators, significant difference was found in all sub-dimensions, $\mathrm{p}=.00<.05$. When test results are examined, it is seen that $\mathrm{t}$ values are negative. This indicates that the teachers' perceptions negatively separated from administrator perceptions. In all sub-dimensions, it is seen that the weighted mean of responds by the teachers is lower than weighted means of the responds provided by the administrators. 
3.7 Variation in Teachers Perceptions of Administrators' Instructional Leadership Behaviors in terms of Gender

Table 8. Variation in teachers' and administrators' perceptions of instructional leadership behaviors in terms of gender

\begin{tabular}{|c|c|c|c|c|c|c|c|}
\hline Sub-Dimensions of the scale & Gender & $\mathbf{n}$ & $\overline{\mathbf{X}}$ & $\mathbf{F}$ & $\mathbf{t}$ & Df & $\mathbf{P}$ \\
\hline \multirow{2}{*}{$\begin{array}{l}\text { Determining and Sharing the } \\
\text { school's aims }\end{array}$} & female & 166 & 3,56 & 3,84 & ,59 & 276,24 &, 55 \\
\hline & male & 143 & 3,52 & & & & \\
\hline \multirow{2}{*}{$\begin{array}{l}\text { Management of Educational } \\
\text { Program and instruction process }\end{array}$} & female & 166 & 3,39 & 6,03 &, 15 & 272,59 & ,88 \\
\hline & male & 143 & 3,38 & & & & \\
\hline \multirow{2}{*}{$\begin{array}{l}\text { Assessment of Education } \\
\text { process and students }\end{array}$} & female & 166 & 3,35 & ,35 &, 12 & 299,25 & ,90 \\
\hline & male & 143 & 3,34 & & & & \\
\hline \multirow{2}{*}{$\begin{array}{l}\text { Supporting teachers and their } \\
\text { development }\end{array}$} & female & 166 & 2,82 & 6,30 &,- 55 & 275,50 &, 57 \\
\hline & male & 143 & 2,88 & & & & \\
\hline \multirow{2}{*}{$\begin{array}{l}\text { Creating an } \begin{array}{r}\text { organized } \\
\text { learning-teaching } \\
\text { and atmosphere }\end{array} \\
\text { environment }\end{array}$} & female & 166 & 3,27 & 2,28 & 01 & 292,27 & ,98 \\
\hline & male & 143 & 3,27 & & & & \\
\hline
\end{tabular}

When Table 8 is examined, it is seen that according to the results of the t-test conducted to find out whether secondary school teachers' perceptions of instructional leadership behaviors vary in terms of gender, it was found that secondary school teachers' perceptions of instructional leadership behaviors of administrators do not show significant difference in terms of gender $\mathrm{p}>.05$.

3.8 Variation in Teachers' Perceptions of Administrators' Instructional Leadership Behaviors in terms of Length of Service

Table 9. Variation in teachers' perceptions of administrators' instructional leadership behaviors in terms of length of service

\begin{tabular}{|c|c|c|c|c|c|c|}
\hline $\begin{array}{l}\text { Sub-Dimensions } \\
\text { of the scale }\end{array}$ & $\begin{array}{l}\text { Source of } \\
\text { Variance }\end{array}$ & $\begin{array}{l}\text { Sum of } \\
\text { Squares }\end{array}$ & $\begin{array}{l}\text { Degree of } \\
\text { Freedom } \\
\text { (df) } \\
\end{array}$ & $\begin{array}{l}\text { Mean of } \\
\text { Squares }\end{array}$ & $\mathbf{F}$ & $\mathbf{P}$ \\
\hline $\begin{array}{l}\text { Determining and } \\
\text { Sharing the } \\
\text { school's aims }\end{array}$ & $\begin{array}{l}\text { Between Groups } \\
\text { Within groups } \\
\text { Total }\end{array}$ & $\begin{array}{l}12,03 \\
120,13 \\
132,16\end{array}$ & $\begin{array}{l}4 \\
304 \\
308\end{array}$ & $\begin{array}{l}3,00 \\
, 39\end{array}$ & 7,61 & ,00 \\
\hline $\begin{array}{l}\text { Management of } \\
\text { Educational } \\
\text { Program and } \\
\text { instruction process }\end{array}$ & $\begin{array}{l}\text { Between Groups } \\
\text { Within groups } \\
\text { Total }\end{array}$ & $\begin{array}{l}12,38 \\
120,35 \\
132,74\end{array}$ & $\begin{array}{l}4 \\
304 \\
308\end{array}$ & $\begin{array}{l}3,09 \\
, 39\end{array}$ & 7,82 &, 00 \\
\hline $\begin{array}{l}\text { Assessment of } \\
\text { Education process } \\
\text { and students }\end{array}$ & $\begin{array}{l}\text { Between Groups } \\
\text { Within groups } \\
\text { Total }\end{array}$ & $\begin{array}{l}18,24 \\
168,96 \\
187,21\end{array}$ & $\begin{array}{l}4 \\
304 \\
308\end{array}$ & $\begin{array}{l}4,56 \\
, 55\end{array}$ & 8,20 &, 00 \\
\hline $\begin{array}{l}\text { Supporting } \\
\text { teachers and their } \\
\text { development }\end{array}$ & $\begin{array}{l}\text { Between Groups } \\
\text { Within groups } \\
\text { Total }\end{array}$ & $\begin{array}{l}17,94 \\
172,72 \\
190,67\end{array}$ & $\begin{array}{l}4 \\
304 \\
308\end{array}$ & $\begin{array}{l}4,48 \\
, 56\end{array}$ & 7,89 &, 00 \\
\hline $\begin{array}{l}\text { Creating an } \\
\text { organized } \\
\text { learning-teaching } \\
\text { environment and } \\
\text { atmosphere }\end{array}$ & $\begin{array}{l}\text { Between Groups } \\
\text { Within groups } \\
\text { Total }\end{array}$ & $\begin{array}{l}21,57 \\
159,19 \\
180,76\end{array}$ & $\begin{array}{l}4 \\
304 \\
308\end{array}$ & $\begin{array}{l}5,39 \\
, 52\end{array}$ & 10,29 &, 00 \\
\hline
\end{tabular}


According to Anova results, secondary school teachers' perceptions of school administrators' instructional leadership behaviors vary in terms of length of service $(p=.00<.01)$. According to this result, there is a significant difference between teachers' perceptions of school administrators' instructional leadership behaviors in terms of the length of service.

\subsection{Teachers' Perceptions of Administrators Instructional Behaviors in terms of Length of Service}

As variances were not homogeneous, Dunnett's T3 test was conducted in order to reveal which groups of teachers differed in their perceptions of school administrators' instructional leadership behavior. The results are given in Table 10.

Table 10. Variation in teachers' perceptions of administrators' instructional behaviors in terms of length of service

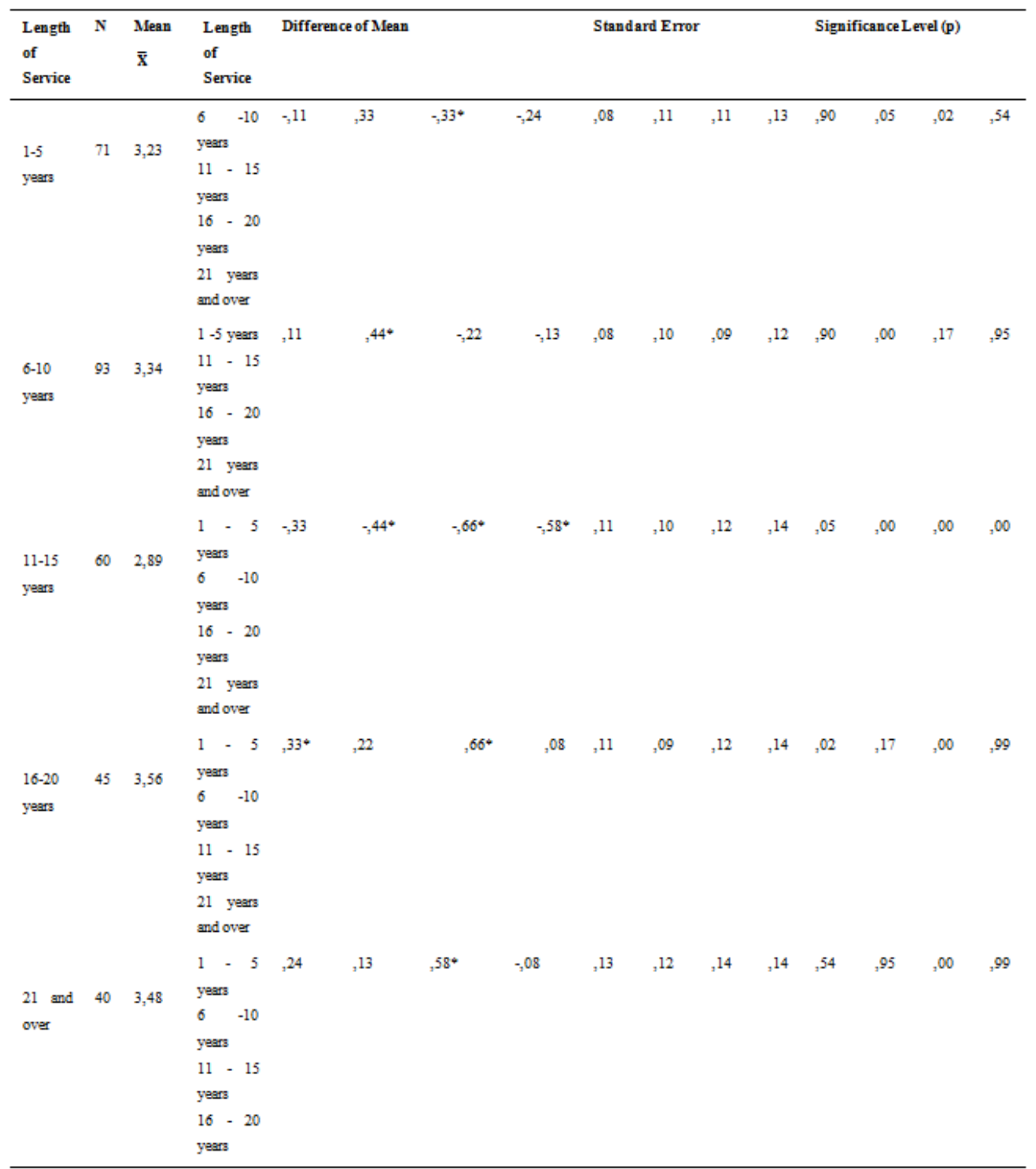


When Table 10 is examined, it is seen that there is a significant difference between the teachers with 1 to 5 years of length of service and the teachers with 16 to 20 years length of service $p=, 02<, 05$ in terms of their perceptions of instructional leadership behaviors of school administrators. A significant difference between the teachers with 6 to 10 years of length of service and the teachers with 11 to 15 years length of service in terms of their perceptions of instructional leadership behaviors of school administrators $p=, 00<, 05$. A significant difference was also found between the teachers with 11 to 15 years of length of service and the teachers with 16 to 20 years length of service in terms of their perceptions of instructional leadership behaviors of school administrators $p=, 00<, 05$. Besides, a significant difference was also found between the teachers with 11 to 15 years of length of service and the teachers with 21 years and over length of service, $p=, 02<, 05$. When the weighted means of teachers' responds to the questions about the frequency instructional leadership behaviors exhibited are considered, it is seen that while the perceptions of the teachers with service length of 1 to 5 years $(\bar{X}=3,23)$, the teachers with 6 to 10 years of length of service $(\bar{X}=3,34)$, with 11 to 15 years of length of service $(\bar{X}=2.89)$ about instructional leadership behaviors is that they are exhibited "occasionally", the teachers with 16 to 20 years of service length ( $\bar{X}=3,56$ ) and the teachers with service length of 21 years and over $(\overline{\mathrm{X}}=3,48)$ think that they are exhibit "Most of the time". While the responds teachers with 11 to 15 years of length of service provided is the lowest with a mean of $\bar{X}=2.89$, the responds teachers with 16 to 20 years of length of service is the highest with a mean of $\bar{X}=3,56$.

\section{Discussion and Conclusion}

According to the teachers who participated in the study, while the behavior of "determining aims to increase students' current level of success" is the most commonly exhibited behavior, the behaviors of "revising the aims of the schools and updating them" is the least commonly observed behavior in the dimension of determining and sharing school's aims. According to the administrators, while "making use of students' level of success when developing schools aims" is the most commonly exhibited behavior, the behaviors of "encouraging everyone to have high expectations for students' success" is the least commonly exhibited behavior.

According to the teachers' perceptions of the school administrators' instructional leadership behaviors in the process of management of Educational Program and instruction process, while the behavior of "preparing annual activity report about school's educational activities" is the most widely behavior exhibited by school administrators, the behavior of "visiting classes to ensure the effective use of in-class instruction time" is the least exhibited one. According to the administrators, while "attaching importance to taking student needs and expectations into consideration in the school's program" is the most commonly exhibited behavior, "actively taking part in the evaluation and selection of materials (books, journals etc.) for the program" is the least observed behavior. Accordingly, it has been revealed that there is a significant difference between teachers' and administrators' perceptions. In Turkey, Higher Education Council and World Bank (1999) also determined some curricular standards, some of which are consistency of the teaching and learning approaches in the program with the objectives and the grade level of the students, and consistency between the program and the practice. The instructors should explain the relationship between the program and the lessons clearly (Cited; Ok \& Eret 2010).

According to the teachers' and administrators perceptions of the frequency administrators exhibit instructional leadership behaviors in the educational process and students' assessment, the behavior of "informing teachers about school success written or orally' is the most commonly observed behavior, while the least commonly observed behavior is "revising students' works when assessing in-class teaching". However, when the weighted means of the behaviors in the sub-dimension of assessment of instructional process and students are considered, it is seen that the teachers think that these behaviors are seen "Occasionally" $(\bar{X}=3,34)$, while the administrators stated that they exhibited these behaviors "Most of the Time" ( $\overline{\mathrm{X}}=3,95)$. According to these results, a difference between teachers' and administrators' perceptions has been revealed. In a study by Sağır and Memişoğlu (2012), according to the teachers views it was determined that the behaviors related with "assessment and education process and students" sub-dimension, adminisrators show more rewarding behaviors to the students have superior success with behavior in school, after classroom observetions, administrata show less frequently than the others to explain behavior related teaching.

According to the teachers' perceptions of the frequency the school administrators exhibit instructional behaviors in the sub-dimension of supporting teachers and their professional development, while the most commonly exhibited behavior by the administrators is "encouraging teachers to exhibit high level of performance", "calling speakers to give conference for teachers " is the least commonly exhibited behavior. According to the administrators, "complimenting teachers for their outstanding efforts and success" is the behavior they exhibit most commonly, "arranging meetings to share new knowledge and skills acquired in-service trainings" is the least commonly exhibited behavior. However, when the weighted mean of the responds to the questions about the frequency of 
behaviors in the sub-dimension of supporting teachers and their development is considered, it is seen that while the teachers think that these behaviors are exhibited occasionally $(\overline{\mathrm{X}}=2,85)$, the administrators state that they exhibit them most of the time $(\overline{\mathrm{X}}=3,47)$. According to this result, it has been revealed that there is a difference between teachers' and administrators' perceptions.

According to the teachers' perceptions of the school administrators' exhibition of the instructional leadership behaviors in the sub-dimension of creating organized learning-teaching environment and atmosphere, while the behaviors of "preventing harm to school due to conflicts between individuals and groups" and "providing family and environment support to increase student success" are the most commonly observed behaviors, "encouraging social activities that will ensure coalescence among teachers and students" is the least commonly observed behavior. According to the administrators, while the behavior of "supporting teachers to do their jobs better" is the most commonly exhibited behavior, "encouraging "team spirit" among administrators, teachers, students and other staff" is the least commonly exhibited behavior. In a similar study by Shonta and Smith (2007), it was determined that teachers' perceptions of instructional leadership behaviors to achieve administrators' level of school principals, is lower than administrators' self perceptions. The teachers' perceptions of school administrators' instructional leadership behaviors revealed that there was no significant difference in terms of their length of service.

In a study by Aksoy (2006), it was concluded that school administrators frequently exhibited the behavior of determining aims to increase students' current level of success. In another study by Işık and Aksoy (2008), it was concluded that according to teachers' perceptions, school administrators exhibited behaviors of rewarding students successful at class level or at school level more compared to the other behaviors. On the other hand, when assessing in-class instruction, it was concluded that they exhibited the behavior of revising student works when assessing in-class teaching less frequently compared to the other behaviors. In a study by Can (2007), it was found that school administrators exhibited behavior of arranging events that will contribute to the development of teachers at very low levels. When the studies on this issue are examined, it is seen that school administrators do not exhibit behaviors of contributing to the professional development of teachers at adequate level. Training and development of teachers professionally is to be handled with great importance and school administrators' opportunities and chances for arranging such events are to be increased. In a similar study by Argon and Mercan (2009), it was determined that school administrators exhibit the behaviors of encouraging social activities that will ensure coalescence among teachers and students, and encouraging "team spirit" among administrators, teachers, students and other staff very rarely, while they exhibited the behaviors of preventing harm to school due to conflicts individuals and groups, and ensuring family and environment support for student success more frequently. When the results of the studies are examined, it is seen that they are in parallel with the results of this study.

According to the results of the study, it has been revealed that there is a significant difference between the perceptions of secondary school teachers and school administrators about school administrators' instructional leadership behaviors. In all dimensions, compared to the administrators, the teachers think that school administrators exhibit instructional leadership behaviors at lower levels. In a study by Sağır (2011), a significant difference between administrator and teachers was found in terms of their perceptions of instructional leadership perceptions. In all sub-dimension of instructional leadership, administrators' perceptions are higher than teachers' perceptions. Thinking that this difference of perception between teachers and administrators will lead to disagreements, school administrators are to be more objective and open to criticisms, and create a more dynamic communication environment in the school. School administrators are to be open to criticisms and teachers are to be given chances to assess them.

The teachers' perceptions of school administrators' instructional leadership behaviors do not vary in terms of gender. In a study by Akalın Akdağ (2009) in which the effectiveness of elementary school administrators' instructional leadership behaviors in the application of the new elementary school program was investigated, no significant difference between teachers' perceptions of administrators' instructional leadership behaviors in terms of gender was found.

The teachers' perceptions of the frequency school administrators exhibit instructional leadership show significant difference in terms of their length of service. There is significant difference between the perceptions of teachers with 1 to 5 years of length of service and teachers with 16 to 20 years of length of service. There is also a significant difference between the perceptions of teachers with 11 to 15 years of length of service and teachers with 6 to 10 years of length of service and teachers with 16 to 20 years of length of service and teachers with 21 and more years of length of service. When the results are examined, it is seen that the weighted mean of the responds teachers with 16 to 20 years of length of service provided differ positively from the other groups. It is seen that the weighted mean of the responds of the teachers with longer length of service is higher compared to the other groups. According to the 
results of the study by Derbedek (2008), it was also found that perceptions of the teachers with 21 years and longer length of service about school administrators' instructional leadership behaviors were higher compared to the teachers with 6 to 10 years and 11 to 15 years of length of service. In this context, school administrations are to be more objective and raise "team spirit" among all partners.

Studies are to be carried out to make schools more interesting and more peaceful for students and teachers and to create a positive atmosphere. Social activities can be organized for the coalescence of school partners and for raising team spirit among them. By ensuring a positive communication atmosphere in the school, an environment where people can express themselves is to be created. Conflicts that can harm the school are to be prevented. According to the results of the study by Sayin (2010), school administrators' behavior that preventing damage to the school from the conflict between the individuals and groups has been most widely adopted by teachers, and similar results to this study.

In a study by Blase and Blase (1999), aimed that, determining effective instructional leadership characters and the factors that influence positively teaching process in the class of school administrators. As a result of the study it was determined that exhibit such behaviors are more successful school administrators; supporting interpersonal relations among teachers, giving aouthority to the teachers and not to fear for their professional development, to cooperate with teachers, to include teachers in the decision-making process at school, talking about learning and teaching process with teachers freely.

Adequate numbers of quality in-service trainings are to be held by the MEB (Ministry of National Education in Turkey) and teachers are to be encouraged to attend to them. To achieve this, cooperation with universities can be made and support from faculty members can be sought. School administrators are to be authorized to reward teachers in writing and objective performance assessment studies are to be carried out. Teachers are to be given opportunities to develop themselves along appropriate carrier stages (supervisor etc.). Recent developments in education can be followed and meetings to inform teachers about them can be held at certain intervals. Teachers can be encouraged to set an example for other teachers with the professional development they show in the education environment.

School administrators should identify behaviors that are expected from teachers and try to do necessary work. Several surveys can be done to learn expectations of teachers, moreover, more inclusive work environment, teachers are active in the management process, can be created.

\section{References}

Açıkalın, A. (1997). Okul Yöneticiliği. Ankara: Pegem Yayıncılık.

Akalın Akdă̆, G. (2009). İlköğretim Okul Müdürlerinin Öğretimsel Liderlik Davranışlarının Yeni İlköğretim Müfredatının Uygulanmasındaki Etkililik Düzeyi. (Yüksek Lisans Tezi, Kocatepe Üniversitesi Sosyal Bilimler Enstitüsü, Afyon). Retrieved from http://tez.yok.gov.tr/Ulusal Tez Merkezi.

Aksoy, E. (2006). İlköğretim Okulu Yöneticilerinin Öğretimsel Liderlik Rolleri. (Yüksek Lisans Tezi, On Sekiz Mart Üniversitesi Sosyal Bilimler Enstitüsü, Çanakkale). http://tez.yok.gov.tr/Ulusal Tez Merkezi.

Argon, T. \& Mercan, M. (2009). İlköğretim Okulu Yöneticilerinin Öğretim Liderliği Rollerini Gerçekleştirebilme Düzeyleri. Atatürk Eğitim Fakültesi ve MEB öğretmen Yetiştirme ve Eğitimi Genel Müdürlüğü Kongre Bildirisi, Marmara Üniversitesi, İstanbul.

Arslan, M. (2009). Yeni İlköğretim Programının Uygulanmasında İlköğretim Okulu Yöneticilerinin Öğretimsel Liderlik Rollerine İlişkin Öğretmen Görüşleri. (Yüksek Lisans Tezi, Gazi Üniversitesi Eğitim Bilimleri Enstitüsü, Ankara). Retrived from http://tez.yok.gov.tr/Ulusal Tez Merkezi.

Aydın, M. (2010). Eğitim Yönetini. Ankara: Hatipoğlu Yayınevi.

Başaran, İ. E. (1991). Örgütsel Davranış. Ankara: Kadığlu Matbaası.

Başaran, İ.E. (1994). Eğitim Yönetimi, Ankara: Gül Yayınevi.

Başaran, İ.E. (1998). Yönetimde İnsan İlişkileri. Ankara: Kadıŏlu Matbaası.

Blase, J. \& Blase, J. (1999). Principals' Instructional Leadership and Teacher Development: Teachers' Perspectives. Educational Administration Quarterly. 35 (3), 349-378. Do1: EJ589458 ISNN: ISNN-0013-161X.

Camburn, E., Brian R., Taylor, J.E. (2003). Distributed Leadership in Schools: The Case of Elementray Schools Adopting Comprehensive School Reform Models, Educational Evaluation and Policy Analysis, Winter, 25(4), 347-373.

Can, N. (2007). İlköğretim Okulu Yöneticisinin Bir Öğretim Lideri Olarak Yeni Öğretim Programlarının 
Geliştirilmesi ve Uygulanmasındaki Yeterliliği. Eğitimde Kuram ve Uygulama. Retrieved from http://eku.comu.edu.tr/index/3/2/ncan.pdf

Creswell, John W. (2013). Araştırma Deseni, Nitel, Nicel ve Karma Yöntem Yaklaşımları (Çev. S. B. Demir). Ankara: Eğiten kitap.

Çelik, V. (2003). Eğitimsel Liderlik. Ankara: Pegem A Yayınları.

Daresh, J. \& Liu, C. J. (1985). High School Principals' Perceptions Of Their İnstructional Leadership Behavior. Paper Presented al The Annual Meeting of The American Educational Research Association (Chicago, IL. March 31 - April 4), 22. Retrieved from files.eric.ed.gov/fulltext/ED291138.pdf

De Bevoise, W. (1984). Synthesis Of Research On The Principal As instructional Leader. Educational Leadership, 41(5), 14-20. Retrieved from http://www.ascd.org/ASCD/pdf/journals/ed_lead/el_198402_bevoise.pdf

Derbedek, H. (2008). İlköğretim Okul Müdürlerinin Öğretimsel Liderlik Özelliklerinin Öğretmenlerin Özyeterlilikleri Üzerindeki Etkileri (Bursa ili örneği). (Yüksek Lisans Tezi, Pamukkale Üniversitesi Sosyal Bilimler Enstitüsü, Pamukkale).

Drucker, P.F. (1996). Yeni Gerçekler. (Çev. B. Karanakçı). Ankara: Türkiye İş Bankası Kültür Yayınları.

Erdoğan, İ. (2008). Eğitim ve Okul Yönetimi. İstanbul: Sistem Yayıncılık.

Eret, E. \& Ok, A. (2010). Prospective English teachers' views on the physical environment, human resources, and program of their departments. Asia Pacific Educ. Rev. 11:533-540. http://dx.doi.org/10.1007/s12564-010-9100-6

Hoy, W. K. ve Miskel, C. G. (2010). Eğitim Yönetimi Teori, Araştırma ve Uygulama. (Çev. S. Turan). Ankara: Nobel Yayın Dağıtım.

Işık, H. \& Aksoy, E. (2008). İlköğretim Okul Müdürlerinin Öğretim Liderliği Rolleri. Kırgızistan Manas Üniversitesi Sosyal Bilimler Dergisi. 8(19), 235-249. Retrieved from journals.manas.edu.kg

İnandı, Y., Özkan, M. (2006). Resmi İlköğretim Okulları ve Liselerde Görev Yapan Yönetici ve Öğretmenlerin Görüşlerine Göre Müdürler Ne Derece Öğretim Liderliği Davranışları Göstermektedir? Mersin Üniversitesi Eğitim Fakültesi Dergisi, 2(2), 123-149. Retrieved from dergipark.ulakbim.gov.tr/mersinefd/ article/ viewFile/5000002945/5000003447

Memişoğlu, S. P. ve Sağır, M. (2012). İlköğretim Okulu Yöneticilerinin Öğretimsel Liderlik Rollerine İlişkin Öğretmen ve Yönetici Algıları. Ĕgitim ve Öğretim Araştırmaları Dergisi, 1(2), 1-12. Retrieved from www.jret.org.

Özdemir, S. (2000). Eğitimde Örgütsel Yenileşme, Ankara: Pegem A Yayıncılık.

Özdemir, S. ve Sezgin, F. (2000). Etkili Okullar ve Öğretim Liderliği. Ankara: Gazi Eğitim Fakültesi Eğitim Bilimleri Bölümü Sosyal Bilimler Dergisi. 266-282, Retrieved from s3amozonaws.com/academia.edudocuments/30495625.

Öztaş, N. (2010). Okul Müdürlüğ̈̈nden Eğitim Liderliğine Geçiş ve Karaman İli Örneği.( Yüksek Lisans Tezi, Karamanoğlu Mehmet Bey Üniversitesi, Sosyal Bilimler Enstitüsü, Karaman).

Özmen, F. (2003). Liderlik Tarzları ve Okul Yöneticilerinin Liderlik Eğitimi. Eurian Journal of Education Research. Retrieved from www.ejer.com.tr

Sağır, M. (2011). İlköğretim Okulu Yöneticilerinin Öğretimsel Liderlik Rolleri ve Karşılaştıkları Sorunlar. ( Doktora Tezi, Abant İzzet Baysal Üniversitesi Sosyal Bilimler Enstitüsü, Bolu.)

Sayın, E. (2010). Öğretimsel Liderlik ve İlköğretim Okulu Yöneticileri Üzerine Bir Araştırma. (Yüksek Lisans Tezi, On Sekiz Mart Üniversitesi, Sosyal Bilimler Enstitüsü, Çanakkale).

Shonta M., Smith B.S. (2007). Principals' and Teachers' Perception of Principals' Instructional Leadership, Saint Luis University.

Şişman, M. (1997). Okul Müdürlerinin Öğretim Liderliği Davranışları. IV. Eğitim Bilimleri Kongresi. Anadolu Üniversitesi, Eskişehir.

Şişman, M. (2004), Öğretim Liderliği. Ankara: PegemA Yayınları.

Yörük, S., Akdağ Akalın, G. (2010). İlköğretim Okul Müdürlerinin Öğretimsel Liderlik Davranışlarının Etkililiği Ölçeğinin Geliştirilmesi. Kuramsal Eğitim Bilim, 3(1), 66-92, Retrieved from www.keg.aku.edu.tr/arsiv/c3s1/c3s1m5.pdf 